Рад примљен: 17. 4. 2020.

Рад прихваћен: 10. 8. 2020.

Original paper \begin{tabular}{l} 
Živorad M. Milenović \\
\cline { 2 - 3 }
\end{tabular}

Biljana S. Jeremić

University of Novi Sad, Faculty of Education in Sombor, Serbia

Danijela M. Sudzilovski

University of Kragujevac, Faculty of Education in Užice, Serbia

\title{
Perceptions Of Pre-Service Primary School Teachers Regarding the Application of Interactive Educational Software in Classroom Teaching ${ }^{2}$
}

\begin{abstract}
Summary: The Interactive Educational Software in Classroom Teaching (IESCT) represents computer programs used for the independent design of educational content that is to be acquired. The starting point of this research was the general assumption that IESCTs significantly contribute to the effectiveness of classroom teaching and the learning and participation of students in classes. The starting points were also the specific assumptions that the research would identify the components that indicate the most common contributions of IESCTs and that it would establish a significant difference in the estimates of the pre-service teachers regarding the contribution of the IESCTs relative to their academic achievement. To establish this, the research presented in this paper was conducted in the second half of 2019 on a sample of 83 pre-service primary school teachers at the Faculty of Education in Prizren (Republic of Serbia). The data were generated by the IESCT Scale $(\alpha=.912)$. The factor analysis identified two components that indicate the contribution of the IESCT: 1) the efficiency of
\end{abstract}

\footnotetext{
1 zivorad.milenovic@pr.ac.rs

2 This paper was written as part of science project Kosovo and Metohija between national identity and European integrations, ID III47023 which has been funded by the Ministry of Education, Science and Technological Development of Republic of Serbia since 2010; two projects funded by the Ministry of Education and Culture of the Republic of Srpska (Bosnia and Herzegovina): 1) The development of software for identifying talent in students, ID 19/6-020/961-26/1; and 2) Software support for prediction of student success in studying, ID 19/6-020/961-27/18.; and the scientific and professional project Social Phenomena and Modern Schools: Innovations in Teaching in the Function of Efficient Adoption of Content About Human Society, ID 06-4-2/20, financially supported by the Faculty of Education in Sombor, University of Novi Sad.

Copyright ( 2020 by the authors, licensee Teacher Education Faculty University of Belgrade, SERBIA.

This is an open access article distributed under the terms of the Creative Commons Attribution License (CC BY 4.0) (https://creativecommons.org/licenses/by/4.0/) which permits unrestricted use, distribution, and reproduction in any medium, provided the original paper is accurately cited.
} 
teaching and 2) individuality in learning. The analysis of variance revealed that there was a significant difference in the estimates of the four groups of students, grouped according to their academic achievement. Based on the critical comparative analysis presented in the paper and the results of the empirical research, a proposal was given for introducing innovative approaches to classroom teaching in schools in the Republic of Serbia and for its implementation in accordance with innovative didactic and methodological models that include the use of interactive educational software in teaching.

Keywords: e-learning, educational software, software implementation, individuality in learning, innovative learning models.

\section{Introduction}

Research results published in world's leading journals (Kopcha et al., 2016; Wang et al., 2018; Olasina, 2019; Zsoldos Marchis, 2014) indicate that interactive educational software is widely used in developed education systems worldwide and that its use is highly efficient in achieving learning and student participation in the classroom. In contrast, in the Republic of Serbia, this important and current topic has been insufficiently researched, and so far, mostly tangential research has been conducted, only partially looking at this problem. In one such research of the cognitive style of the pre-service primary and preschool teachers, it was found that almost half of the students simultaneously possess the characteristics of innovative and adaptive cognitive styles. Also, a higher level of adaptability was determined in students with better achievements, who attended senior years of study (Marić et al., 2018: 61). Some research has shown that innovative ICT models based on the implementation of numerous tools and applications and interactive educational software significantly contribute to the realization of teaching (Milenovic et al., 2020; Miljković \& Žižović, 2018), but also to the classroom teaching of certain subjects, such as Nature and Human Society (Trbojevic et al., 2015) and Music Education (Pecanas et al., 2016). There have also been studies into the effectiveness of some IT educational platforms, such as the MOODLE platform in foreign language learning (Djukić Mirzajanc, 2019; Gojkov Rajić \& Šafranj, 2019).
The significance of educational platforms in the implementation of teaching especially became evident in schools in the second midterm, i.e. in the summer semester at higher education institutions, in the 2019/20 school year, during the state of emergency declared due to the global pandemic caused by the COVID-19 virus, when classes were organized remotely. Teaching realized in this fashion produced different effects which mainly depended on the ability of teachers and students to use these platforms. The diversity of teachers' levels of professional development in the implementation of ICTs and educational platforms in teaching is also indicated by the results of a research on the contribution of ICTs to the professional development of the secondary vocational school teachers which showed that teachers included in the research "... have a positive attitude towards the use of ICTs in their professional development, that they are trained for their implementation, but that the scope and intensity, as well as the preferred forms of using ICTs in their professional development, differ between them" (Ovesni et al., 2019: 61).

In recent years, interactive educational software has been increasingly introduced in teaching certain subjects in the Republic of Serbia. Educational software represents a programme that was specifically designed for teaching these subjects. There are also many different software solutions for individual subjects. Some of them are specifically tailored for particular areas within a subject, for a particular student age, but also for their capabilities, needs, and interests. All educational software solutions intended 
for classroom teaching are designed to be used by students, in addition to being used by teachers. That is why they are called interactive educational software. Interactive educational software is not used in classroom teaching. In some urban schools, there are teachers who use educational software in the presentation of some parts of their class. These, mostly individual instances of the IESCT use, involve the use of educational software exclusively by teachers who use only some of their features, while there is still an insufficient number of students trained in the use of numerous applications of various educational software solutions, so the prevailing impression is that teachers, who are constantly under pressure to innovate their teaching process, use educational software solely to show that they are working more efficiently, and not necessarily to contribute to a more effective student teaching and learning.

Interactive educational software in classroom teaching is designed so that it can be used to independently shape the teaching content that is being studied. It also includes different tools for the formation of databases, creation of graphics, carrying out various calculations and development of different applications (Magdas \& Bontea, 2011). It also makes significant contributions to the learning of letters, mastering the basic mathematical operations, learning about the environment and relationships in Nature and Society, the realization of Music Education and Visual Art lessons, Physical Education classes and the teaching of elective and optional subjects (Civic Education and Religious Education). The knowledge acquired by younger school-age students in this way is more permanent because it is acquired through their direct involvement in their learning, independent research, and inventive activity. In this way, students also acquire a better basis for further learning of a more complex teaching content.

An effective implementation of IESCT requires, among other things, a conducive environment. It implies both the material equipment of the school, teachers trained in methodology, well- versed in the application of IESCT, and an environment that supports and favours the use of software in teaching (Pecanac et al, 2016). One of the problems encountered with the implementation of IESCT is the inability to overcome any shortcomings or the identified insufficient efficacy of certain educational software solutions (Quinlan, 2016). The lack of efficacy in the implementation of IESCT also arises in certain teaching situations in which students have not been adequately trained by their teachers in using certain educational software tools and applications in an effective manner (Koparan, 2019). These and other problems arise mainly regarding the educational software that was not designed by a joint team of experts in the field of information and communication technology, psychologists and pedagogists, as well as the experts from the direct educational practice, as immediate implementers of teaching with the use of educational software.

Regardless of some of the possible problems encountered in the implementation of IESCT that were mentioned above, IESCT still has considerable effectiveness in student teaching and learning. This is particularly true of the comparative analysis of traditional teaching, based mainly on understanding and memory, and teaching with the use of educational software. This innovative form of teaching is based primarily on evaluation, synthesis and creation, analysis and implementation of knowledge in further learning, and solving of everyday life problems. The knowledge gained in this way is not only more applicable than the knowledge acquired in a traditional setting, but it is also more permanent. The problem of the research that was conducted is precisely the IESCT, i.e., its significance and educational efficiency in teaching, learning, and student participation.

\section{Method}

The aim of the research is to determine the contribution of interactive educational software in 
classroom teaching. The starting point of the research was the general assumption that IESCT significantly contributes to the effectiveness of classroom teaching, learning and student participation in teaching, and also the specific assumption that this research will help isolate the components indicating the most common contributions of IESCT, as well as that a significant difference will be determined in student assessment of the contribution of IESCT, based on their academic achievement.

The research was conducted in the second half of 2019, on a sample of 83 students attending the Classroom Teaching Study Programme at the Faculty of Education in Prizren (Republic of Serbia). The structure of the sample according to academic achievements during studies was as follows: 1) grade point average from 6.00 to $7.00-21(25.30 \%) ; 2$ ) grade point average from 7.01 to $8.00-51(61.50 \%)$; 3) grade point average from 8.01 to $9.00-8(9.60 \%)$; and 4) grade point average from 9.01 to $10.00-3$ (3.60\%).

The research used a combined instrument, namely the Interactive Educational Software in Classroom Teaching Scale (IESCT Scale). In addition to the general question on the students' academic achievement during studies, this instrument also consists of a 20 -item scale with a 3-point scale of agreement intensity: 1) I agree; 2) I am not sure; and 3) I disagree. Some of the metric characteristics of the Scale were tested in the research itself by using factor analysis with Varimax rotation and Cronbach's alpha coefficient.

Table 1. KMO test; Bartlett's test of sphericity; Cronbach's alpha coefficient

\begin{tabular}{ccc}
\hline \multicolumn{1}{c}{ KMO } & & .872 \\
\hline & $\chi^{2}$ & 695.85 \\
$\begin{array}{c}\text { Bartlett's test of } \\
\text { sphericity }\end{array}$ & $\mathrm{df}$ & 45 \\
& $\mathrm{p}$ & .000 \\
& $\alpha$ & .912 \\
\hline
\end{tabular}

The KMO test showed a very good value $(\mathrm{KMO}=.872)$. Bartlett's test of sphericity reached statistical significance at the level of $\mathrm{p}<.001$ ( $\mathrm{p}=$ .000 ), indicating the factorability of the matrix and the justification of factor analysis. (Table 1) The reliability of the instrument was examined using the Cronbach's alpha coefficient $(\alpha=.912)$.

The data collected by the research were processed by factor analysis and the analysis of variance and presented in tables and diagrams.

\section{Results}

The data collected by the research were first subjected to the principal component analysis by factor analysis with Varimax rotation.

Table 2. Characteristic roots and percentages of the explained variance after varimax rotation

\begin{tabular}{cccc}
\hline Component & Total & \% of Variance & Cumulative\% \\
\hline 1. & 8.911 & 44.556 & 44.556 \\
2. & 8.709 & 43.544 & 88.100 \\
\hline
\end{tabular}

Using the Guttman-Kaiser criterion, two main components with a characteristic root greater than one were obtained, explaining $88,100 \%$ of the total variance in total. (Table 2)

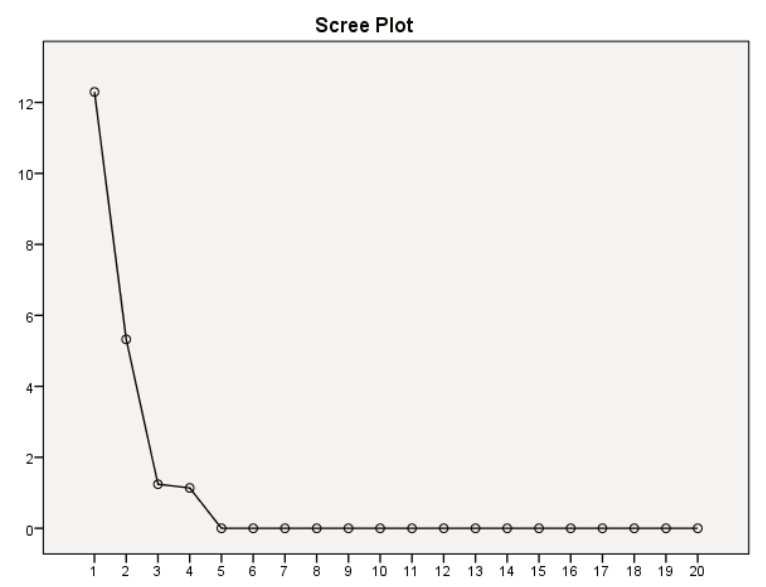

Diagram 1. Cattell's screen test as a criterion for the extraction of a number of factors (Scree Plot) 
The analysis of Diagram 1 shows that the most pronounced fracture is after the second component, which confirms the choice of two components according to the Guttman-Kaiser criterion. The analysis of Diagram 1 shows that the most pronounced break is seen after the third component, which partly deviates from the selection of two components according to the Guttman-Kaiser criterion. Given the nature of the factor analysis to strive for the most optimal selection of components, the choice of the two components according to the Guttman-Kaiser criterion prevailed.

The first component is determined by 18 items: $2,9,11,13,6,18,17,1,5,12,15,8,10,16,3,74$, 19 and 15; it accounts for $44.556 \%$ of the common variance; it was called Effectiveness of Teaching. The second component is determined by 2 items: 4 and
20 ; it accounts for $43.544 \%$ of the common variance; and it was called Individuality in Learning.

The analysis of variance explored the impact of student achievement during their studies on their assessment of the importance of the IESCT. The students were divided into 4 groups based on their academic achievement: 1 (6.00-7.00); 2 (7.01-8.00); 3 (8.01-9.00); and 4 (9.01-10.00).

A statistically significant difference was found at the level of $\mathrm{p}<.05$ in the results of 4 groups of students divided based on their achievements during studies, in their assessment of the importance of the IESCT F $(3 ; 79)=3.499 ; \mathrm{p}=.019$. The actual difference between the mean values of the student groups indicates a medium influence $(\eta=.117)$. (Table 4$)$

Table 3. Rotated matrix of factor structure according to the varimax criterion

\begin{tabular}{lc}
\hline \multicolumn{1}{c}{ Items } & Component \\
\cline { 2 - 2 } a2 Educational software contributes to the effectiveness of teaching. & 1 \\
a9 Children of a younger school-age learn best when they are more involved in their learning. & .882 \\
a11 Educational software plays an important role in interactive teaching. & .882 \\
a13 Use of educational software in teaching contributes to the acquisition of basic knowledge by & .882 \\
students. & .882 \\
a6 The teaching that is constantly implemented in different ways is more effective. & .882 \\
a18 Numerous educational software applications make teaching more obvious. & .882 \\
a17 Educational software significantly contributes to the development of students inventive abilities. & .849 \\
a1 The teachers' ability to use educational software is a significant factor in teaching. & .849 \\
a5 Teachers who use educational software more, achieve better teaching results. & .849 \\
a12 Contemporary teaching is unimaginable without the use of educational software. & .849 \\
a15 Teachers generally do not implement educational software in all subjects. & .849 \\
a8 Educational software is mainly used in the initial teaching of mathematics. & .849 \\
a10 The existence of a database of educational software can significantly improve the quality of & .849 \\
teaching. & .849 \\
a16 Educational software should be tailored to students' educational needs. & .679 \\
a3 During their studies, teachers are not trained in the application of educational software. & .679 \\
a7 The use of educational software is optional, so teachers opt not to use it in teaching. & .679 \\
a19 Educational software does not always contribute to teaching efficiency. & .679 \\
a14 It is advisable to use as many educational software solutions as possible in teaching. & \\
a4 Educational software contributes to the individualization of teaching in all subjects. & .711 \\
a20 Students achieve the best exploration results in teaching when educational software is used. & .711 \\
\hline
\end{tabular}


Table 4. Student achievement during studies and their assessment of the importance of IESCT (ANOVA)

\begin{tabular}{lcccccc}
\hline & Sum of Square & df & Mean Square & F & p & $\eta$ \\
\hline Among Groups & 668.377 & 3 & 222.792 & 3.499 & .019 & .117 \\
Within Groups & 5029.647 & 79 & 63.666 & & & \\
Total: & 5698.024 & 82 & & & & \\
\hline
\end{tabular}

Table 5. Student achievement during studies and their assessment of the importance of IESCT (Descriptive Statistics)

\begin{tabular}{ccccccc}
\hline \multirow{2}{*}{ Achievement } & \multirow{2}{*}{$\mathrm{N}$} & \multirow{2}{*}{ Mean } & \multirow{2}{*}{ SD } & \multirow{2}{*}{ SE } & \multicolumn{2}{c}{ 95\% Confidence Interval for Mean } \\
\cline { 6 - 7 } & & & & & Lower Bound & Upper Bound \\
\hline $7-7$ & 21 & 45.3333 & 6.55235 & 1.42984 & 42.3507 & 48.3159 \\
$8-9$ & 51 & 49.6863 & 8.94760 & 1.25292 & 47.1697 & 52.2028 \\
$9-10$ & 8 & 55.0000 & 3.20713 & 1.13389 & 52.3188 & 57.6812 \\
Total: & 3 & 44.0000 & 6.92820 & 4.00000 & 26.7894 & 61.2106 \\
\hline
\end{tabular}

Based on the data presented in Tables 5 and $\mathrm{SD}=6.55235$ and group 3 (8.01-9.00): $\mathrm{M}=55.0000$; 6 , it can be concluded that the subsequent comparisons using the Tukey's HSD test have shown that the mean values of group 1 (6.00-7.00): $\mathrm{M}=45.3333$; $\mathrm{SD}=6.92820$ - were statistically significantly different. (Table 5)

Table 6. Student achievement during studies and their assessment of the importance of IESCT (Multiple Comparisons)

\begin{tabular}{ccccccc}
\hline $\begin{array}{c}(\mathrm{I}) \\
\text { Achievement }\end{array}$ & $\begin{array}{c}(\mathrm{J}) \\
\text { Achievement }\end{array}$ & $\begin{array}{c}\text { Mean Difference } \\
(\mathrm{I}-\mathrm{J})\end{array}$ & $\mathrm{SE}$ & $\mathrm{p}$ & \multicolumn{2}{c}{ 95\% Confidence Interval } \\
\cline { 6 - 7 } $6-7$ & $7-8$ & -4.35294 & 2.06884 & .161 & -9.7828 & 1.0769 \\
& $8-9$ & $-9.66667^{*}$ & 3.31512 & .023 & -18.3674 & -.9659 \\
& $9-10$ & 1.33333 & 4.92482 & .993 & -11.5922 & 14.2589 \\
$7-8$ & $6-7$ & 4.35294 & 2.06884 & .161 & -1.0769 & 9.7828 \\
& $8-9$ & -5.31373 & 3.03425 & .305 & -13.2773 & 2.6499 \\
& $9-10$ & 5.68627 & 4.74031 & .629 & -6.7550 & 18.1275 \\
$8-9$ & $6-7$ & $9.66667^{*}$ & 3.31512 & .023 & .9659 & 18.3674 \\
& $7-8$ & 5.31373 & 3.03425 & .305 & -2.6499 & 13.2773 \\
$9-10$ & $9-10$ & 11.00000 & 5.40189 & .184 & -3.1776 & 25.1776 \\
& $6-7$ & -1.33333 & 4.92482 & .993 & -14.2589 & 11.5922 \\
& $7-8$ & -5.68627 & 4.74031 & .629 & -18.1275 & 6.7550 \\
& $8-9$ & -11.00000 & 5.40189 & .184 & -25.1776 & 3.1776 \\
\hline
\end{tabular}

The data presented in Table 6 show that a significant difference in the IESCT significance scores at the level of $\mathrm{p}<.05(\mathrm{p}=.023)$ was found between the assessments of group $1(6.00-7.00)$ and group 3 (8.01-9.00). 




Diagram 2. Student achievement during studies and their assessment of the importance of IESCT (Means Plots)

Diagram 2 shows a clear drop in the broken line going from the group of students with GPAs between 8.01 and 9.00 towards the other groups of students, which is in line with the results of the previous research, even though the broken line shows that the difference between the group of students with average grades between 8.01 and 9.00 and the group of students with average grades between 9.01 and 10.00 is more pronounced than the difference between the group of students with average grades between 8.01 and 9.00 and the group of students with average grades between 6.00 and 7.00, as determined by the Tukey HSD test, given that only 3 students with average grades between 9.01 and 10.00 participated in this research. This type of the relationship between the respondents from the sample is quite understandable. Studies of education are multidisciplinary and require that students adopt teaching content from different fields and disciplines. It is unrealistic to expect that there is a large number of students equally capable of achieving top results in all fields, and therefore it is understandable that there is a very small number of students with the highest average grades.

\section{Conclusion and discussions}

The results of the research showed that IESCT significantly contributes to the efficiency of teaching, learning and student participation, but that in Serbia there is still no suitable environment that would favour teaching with the use of the IESCT. Schools and software packages are also insufficiently equipped, and teachers themselves are not adequately trained to implement IESCT in teaching and train students to use IESCT applications in learning. For this reason, it is not possible to speak of the educational efficiency of IESCT in teaching in schools in Serbia (Stanković, 2017). The research confirmed beyond any doubt the quality of teaching with the use of the IESCT, as well as the applicability of the knowledge, skills, habits and abilities acquired through the use of the IESCT in solving students' everyday problems and further learning. The knowledge gained in this way is, in essence, the basic knowledge of students that has value for them outside the classroom.

Two components were identified on the IESCT Scale, which, according to the students attending the Classroom Teaching Study Programme who participated in this research, indicate the highest importance of the IESCT. Students gave highest scores to the items identifying the component that indicates that educational software contributes most to the quality and efficiency of classroom teaching and the component that indicates that educational software contributes to the individualization of learning and student participation in classroom teaching. The research results presented here do not differ significantly from the results of the numerous other studies of this problem, the results of which were published in journals on world's leading publication lists (Bartholomew et al, 2020). The main difference is that in the countries with more advanced education systems, educational software is widely used in teaching and thus the achieved results are also more significant. That is why the results of the worldwide studies on the importance of 
IESCT show that educational software, in addition to its importance in the implementation of teaching, has much greater importance in the teaching and learning of students who, unlike students in Serbia, are trained in using different educational software applications (Anderson \& McCusker, 2019).

Even though the results of this research have shown that there is a significant difference in students' assessments of the importance of the use of educational software in teaching depending on their academic achievement during their studies, it can be concluded that students generally have consistent opinions on the importance of educational software in classroom teaching. This is evidenced by the fact that the difference was found only between the students with GPAs between 6.00 and 7.00 and the students with GPAs between 8.01 and 9.00. Unlike other study programmes, the Classroom Teaching Study Programme is multidisciplinary. During their studies, students acquire different knowledge in the fields of natural and social sciences, physical education, medicine, visual arts and music education. The majority of students have GPAs of up to 8.00, as it is illogical to expect that a larger number of students will be equally knowledgeable in all these disciplines. This is also confirmed by the sample from this research in which $86.80 \%$ students had GPAs of up to 8.00 , an only $9.60 \%$ of the surveyed students had GPAs between 8.01 and 9.00. The existence of a significant difference was certainly influenced by such a large difference in the groups of students divided based on their academic achievements during their studies, so the above results should be interpreted with caution.

The analysis of the factor matrix after rotation can lead to the conclusion that, in general, there is uniform factor saturation. The differences are reflected in thousands, indicating that some of the items were generally answered by students in the same way (Table 3). This is quite understandable as, in the theoretical introduction and in the empirical part of the research, it was confirmed with- out a doubt that, on the one hand, educational software is still generally not used in teaching, or that only certain web tools are used, and on the other, that the implementation of educational software in teaching would significantly contribute to the improvement of the quality of teaching and, above all, to the more efficient learning and participation of students in teaching. All this resulted in the selection of only two components: 1) teaching efficacy, and 2) individuality in learning. These components show, on the one hand, that the organization and implementation of teaching by using educational software would significantly contribute to improving the quality of teaching. It would also contribute to enhanced learning and greater student involvement in teaching. Educational software also significantly contributes to the greater individuality of students in teaching. In order to achieve this, students need to be able to use different educational software applications which contribute not only to more efficient learning, but also to the development of creative and inventive skills.

Generally speaking, students' achievement in the course of their studies significantly influences their opinions on the importance of implementing innovation in teaching. Their assessments of the importance and contribution of educational software in their own learning and participation in classes are also significantly different. Students with a higher academic achievement during their studies have significantly more positive opinions on the importance of the IESCT (Cheng \& Leong, 2017). They are more advantageous than other students, eager for achieving even greater success, and have clearly expressed educational needs to become well versed in the use of educational software in teaching. In a way, this was also confirmed by the results of this research. According to the calculated mean values, the students with GPAs between 8.01 and 96.00 (M $=55.0000$ ) have significantly more positive opinions of the importance of IESCT than the students with GPAs between 6.00 and $7.00(\mathrm{M}=45.3333)$ (Table 5). 
Based on the results of the research and the critical analyses presented in the paper, a need for the introduction of numerous innovations in the professional development of future teachers in Serbia becomes apparent. This applies both to the modification of the classroom teaching study programmes, which currently do not include teaching contents related to the training of students for the application of educational software in teaching, and to their professional development during their teaching practice, which is mandatory in Serbia. It is also necessary to conduct empirical research of this issue, in order to better understand all the benefits and potential problems in the application of educational software in classroom teaching. This would then be a great guide for the improvement of the quality of classroom teaching and the more effective use of educational software in classroom teaching. That this is the case is clearly evidenced by the results of this research on the importance of the IESCT.

\section{References}

- Anderson, J. \& McCusker, M. (2019). Make the Eigenvalue Problem Resonate with Our Students. PRIMUS, 29 (6), 625-644.

- Bartholomew, S., McGraw, T., Fauber, D., Charlesworth, J. \& Weitlauf, J. (2020). Reducing Water Waste through Data-Driven Irrigation Practices. Technology and Engineering Teacher, 79 (4), 21-25.

- Gojkov Rajić, A., Šafranj, J. (2019). Mišljenje studenata o primeni MOODLE platforme za učenje stranog jezika struke. [Students' Opinion on the Application of the MOODLE Platform for Learning a Foreign Language for their Profession]. Inovacije u nastavi, 32 (2), 135-150.

- Đukić Mirzajanc, M. (2019). Efektivnost učenja Nemačkog jezika na platformi Mudl. [The Effectiveness of Learning German on the Moodle Platform]. Inovacije u nastavi, 32 (3), 130-150.

- Kopcha, T., Rieber, L. \& Walker, B. (2016). Understanding University Faculty Perceptions about Innovation in Teaching and Technology. British Journal of Educational Technology, 47 (5), 945-957.

- Cheng, L. \& Leong, S. (2017). Educational Affordances and Learning Design in Music Software Development. Technology, Pedagogy and Education, 26 (4), 395-407.

- Hwang, M. (2018). Graph Processing Using SAP HANA: A Teaching Case. E-Journal of Business Education and Scholarship of Teaching, 12 (2), 155-165.

- Koparan, T. (2019). Examination of the Dynamic Software-Supported Learning Environment in Data Analysis. International Journal of Mathematical Education in Science and Technology, 50 (2), 277-291.

- Magdas, I. \& Bontea, T. (2011). Developing Digital Competences Using Educational Software. A Pedagogical Research, Acta Didactica Napocensia, 4 (4), 31-48.

- Marić, M., Branković, N. i Rodić Lukić, V. (2018). Budući učitelji i vaspitači između tendencije ka prilagođavanju i sklonosti prema inoviranju [Future Teachers and Preschool Teachers Between the Tendency to Adapt and the Tendency to Innovate]. Inovacije u nastavi, 31 (3), 61-73.

- Miljković, B., Žižović, M. (2018). Model IBT 3D tehnologije u sistemu dualnog obrazovanja [Model of IBT 3D Technology in the Dual Education System]. Inovacije u nastavi, 31 (4), 129-144.

- Olasina, G. (2019). Human and Social Factors Affecting the Decision of Students to Accept E-Learning. Interactive Learning Environments, 27 (3), 363-376. 
- Ovesni, K., Stanojević, J. i Radović, V. (2019). Informaciono-komunikacione tehnologije u usavršavanju nastavnika srednjih stručnih škola [Information and Communication Technologies in the Development of Secondary Vocational School Teachers]. Inovacije u nastavi, 32 (3), 61-73.

- Pecanac, R., Jeremic, B. \& Milenovic, Z. (2016). Digital Media in the Teaching of Music Education. The New Educational Review, 43 (1), 236-247.

- Quinlan, J. (2016). Mathematicians' Perspectives on the Utility of Software. International Journal for Technology in Mathematics Education, 23 (3), 103-109.

- Stanković, Z. (2017). Metodički modeli nastave primenom obrazovnih softvera [Methodological Models of Teaching With the Use of Educational Software]. Godišnjak Pedagoškog fakulteta u Vranju [Yearbook of the Faculty of Education in Vranje], 8 (2), 237-252.

- Trbojevic, A., Jeremic, B. \& Milenovic, Z. (2015). Multimedia approach to the development of social concepts in class teaching - a view from the students' perspective. Teme, 39 (3), 867-885.

- Wang, Y., Liu, X. \& Zhang, Z. (2018). An Overview of e-Learning in China: History, Challenges and Opportunities, Research in Comparative and International Education, 13 (1), 195-210.

- Zsoldos Marchis, I. (2014). How In-Service Teachers Develop Electronic Lessons. Acta Didactica Napocensia, 7 (2), 61-67. 
Живорад М. Миленовић

Универзитет у Приштини, Учитељски факултет у Призрену, Косовска Митровица, Република Србија

\title{
Биљана С. Јеремић
}

Универзитет у Новом Саду, Педагошки факултет у Сомбору, Нови Сад, Република Србија

\author{
Данијела М. Судзиловски
}

Универзитет у Крагујевцу, Педагошки факултет у Ужицу, Крагујевац, Република Србија

\section{ПЕРЦЕПЦИЈЕ СТУДЕНАТА - БУДУЋИХ УЧИТЕЉА О ПРИМЕНИ ИНТЕРАКТИВНОГ ОБРАЗОВНОГ СОФТВЕРА У РАЗРЕДНОЈ НАСТАВИ}

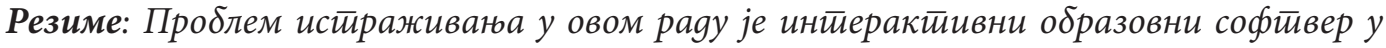



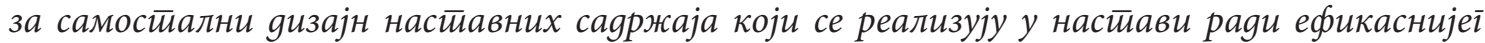

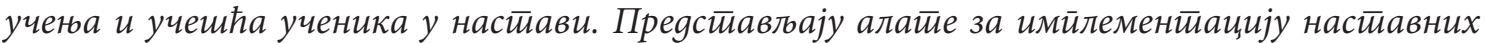
саяржаја, формиране базе йоgайака, за различите иррорачуне, ірафике и яруіе айликаиије иосебно наменене за реализацију настиавних саяржаја у оgређеним настиавним ирееметиима

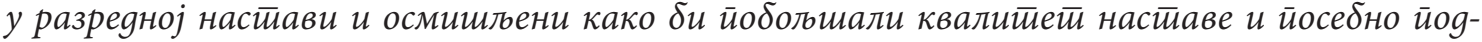

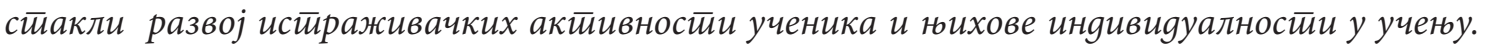

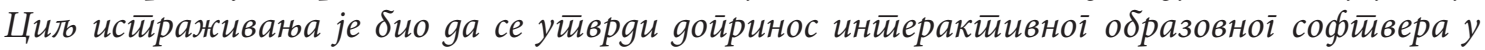

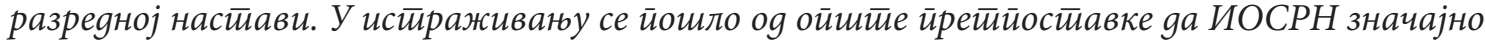

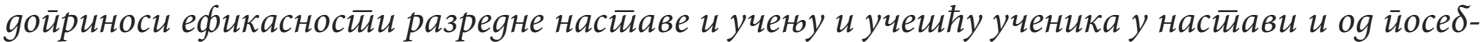

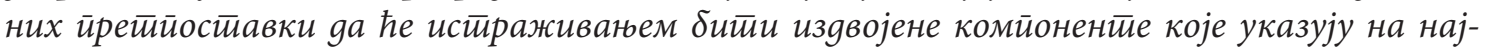
чешће gойриносе ИОСРН, као и gа ће битии уйврђено gа йосйоји значајна разлика у ирроче-

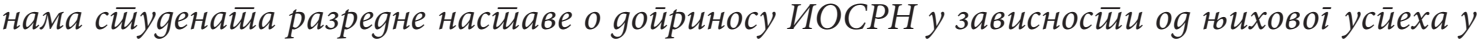

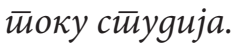

Истираживане је сирровеgено у gруі̄ој йоловини 2019. іодине на узорку оg осамgесети

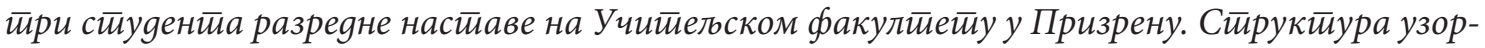

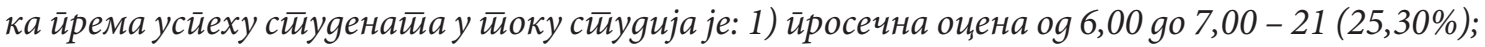
2) ирросечна оцена og 7,01 gо 8,00 - 51 (61,50\%); 3) иросечна оцена og 8,01 gо 9,00 - 8 (9,60\%); и 4) ирросечна оцена оg 9,01 gо 10,00 - 3 (3,60\%). У исираживану је коришћен комбинова-

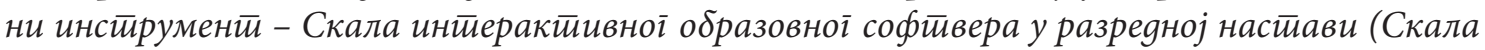

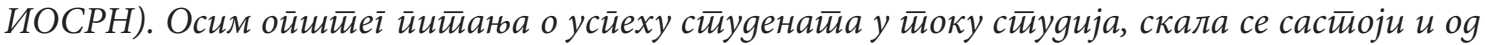

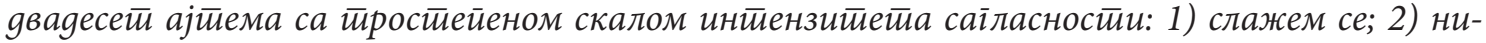
сам сиіуран/на и 3) не слажем се. Неке метиријске каракиетерисииике Скале исиитииване су на самом истираживану факйорском анализом са варимакс ройацијом и Кронбаховим алфа коефицијенитом $(\alpha=0,912)$.

Резулйайи истираживаюа су ӣоказали gа ИОСРН значајно доириноси ебикасностии настиаве и учень и учешћа ученика у настиави, али gа у Србији и gаље не йостиоји оgі̄оварајуће окружеюе које би фаворизовало реализацију настиаве йуйем ИОСРН. Не йостиоји ни 


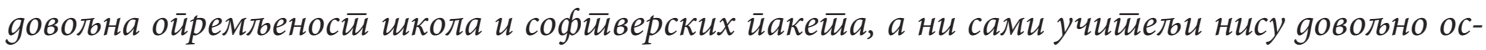
йособлени gа реализују настиаву ирименом ИОСРН и gа обуче ученике gа користе у учењу неке айликације ИОСРН. Из навеgеної разлоїа се и не може іоворитии о васиийнообразовној ефикасностии ИОСРН у настиави у школама у Србији. Истираживанем је уйврђено и gа би

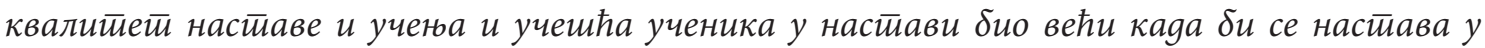
школама у Србији реализовала йрименом ИОСРН. Ученици би у йаквој настиави сиичиали иемельна знаюа, која би за ғих имала вредности и изван учионице и служила би им, како у

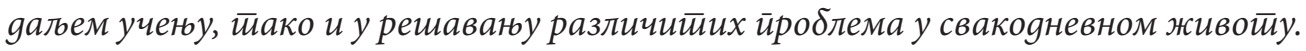

На скали ИОСРН изявојене су gве комйонениее које, иррема ирроценама сииуденайа сйудијскоі йроірама разреgне настиаве обухваћених овим истираживанем, указују на нај-

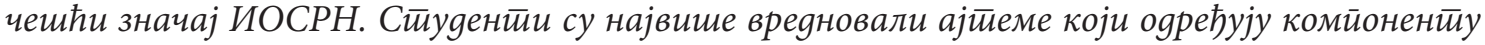

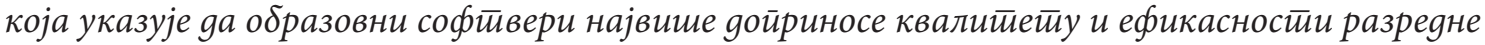

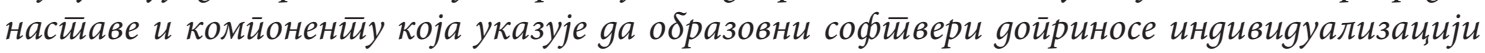
ученьа и учешћа ученика у разредној настиави. Приказани резулитатии истираживана се не разликују значајније оg бројних истираживана овоі йроблема, чији су резулииатии йубликовани у часойисима воgећих светиских листиа. Основна разлика оїлеgа се у йоме ийо у gржавама са развијенијим системемма васиитйана и образована образовни софйвери имају широку

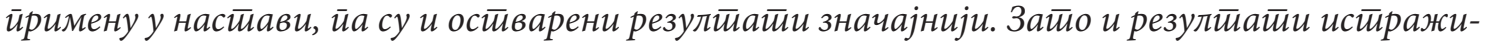
ваюа значаја ИОСРН у светиу йоказују gа образовни софйвери, осим значаја у реализачији

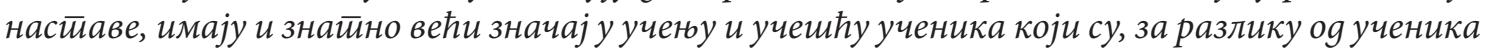
у Рейублици Србији, осиоособлени яа користее различите айликације образовних софбиввера.

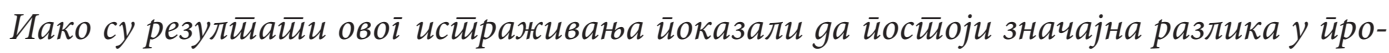

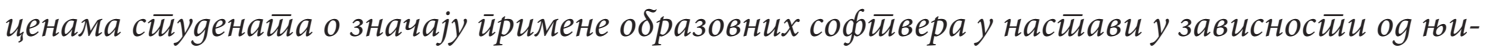

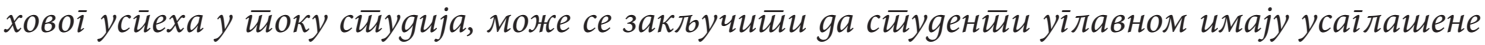
ирроцене о значају образовних софйвера у разредној насйави. На йо уйућује чиненица gа је

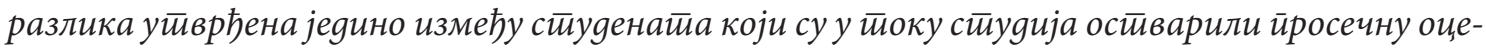

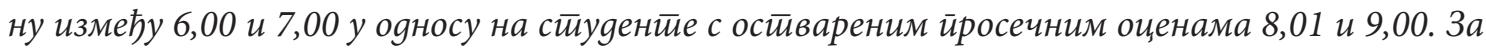

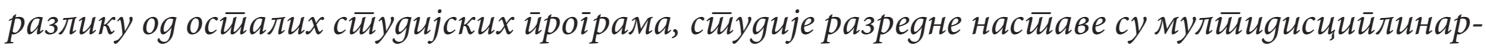

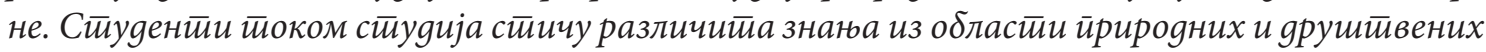
наука, из физичке кулитуре, медицине, ликовне и музиче уметиностии. Највећи број сйудена-

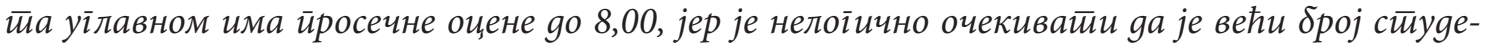

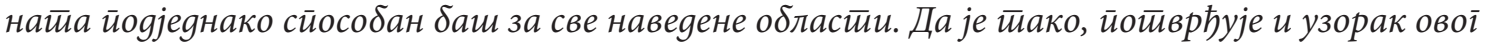
истираживана, у којем је било 86,80\% сииуденайа с ирросечном оценом gо 8,00 а само 9,60\%

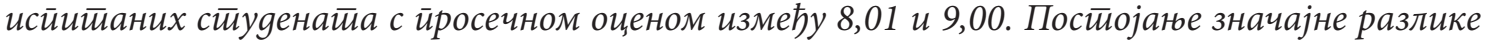
свакако је условила овако велика разлика у іруйама сйуgенайа йрема усиеху у йоку сйуgија,

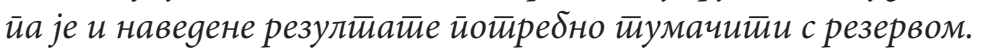

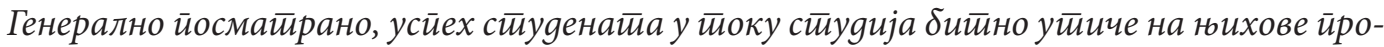
иене у йоїлеgу значаја йримена иновација у насйави. Значајно се разликују и юихове ирроцене о значају и доириносу образовних софйвера у ниховом учену и учешћу у насйави. Знайно

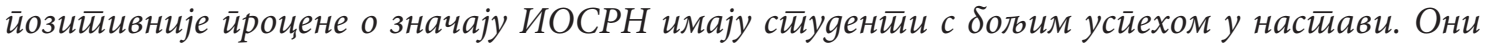

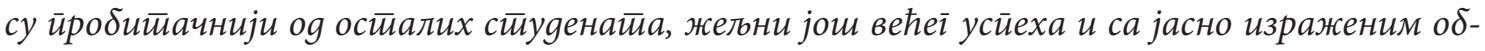
разовним йойребама - gа се шйо боље осйособе gа корисие образовне софйвере у настиави. 
На неки начин је йойврђено и у налазима овоі исиираживаюа, ӣрема израчунайим среgним вредностимма, стиудениии с ирросечном оценом између 8,01 и 9,00 (M=55,0000) имају знайно йозитиивије ирроцене о значају ИОСРН у оgносу на сииуgение с йросечном оценом између 6,00 и 7,00 (М=45,3333) (Табела 5).

На основу резулйайа истираживана и критиччких анализа ӣриказаних у раgу намеће се йойреба gа се у Рейублици Србији увеgу бројне новине у вези са йрофесионалним развојем

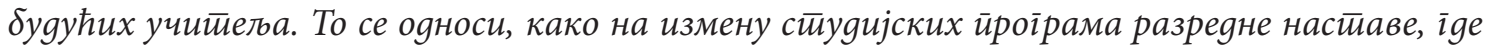

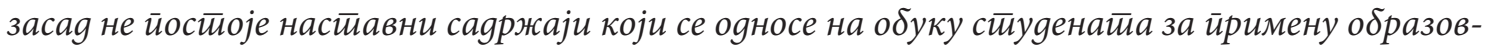

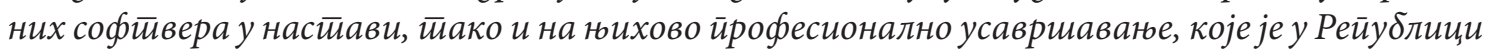
Србији обавезно и у йоку обављьюь учительске йрофесије. Неойхояно је и сировођење емйиријских истираживаюа овоі йроблема како би се саілеgале све йреgностии и моїући йроблеми

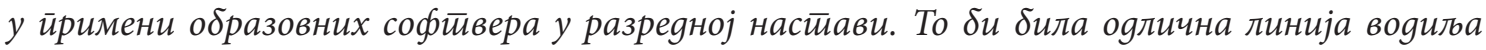
за унайређене квалитетиа разредне настиаве и ефикасније иримене образовних софйвера $у$

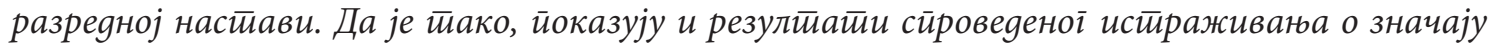
ИОСРН.

Клучне речи: е-учеюе, образовни софйвер, имйлеменйација софйвера, индивияуалности у учењу, иновативни модели учена. 